-168 encoding a 30 -amino-acid peptide ${ }^{3}$. When one considers the deletion of 21 nucleotides ( 7 amino acids) not only is the location of the ORF conserved, but also the structure of the encoded peptide. As shown in the figure, 14 out of 23 positions are identical, 3 conservative changes (Gly) Ala, Val/Leu) have occurred and a lysine residue is located in a central position of both peptides. On the other hand, the nucleotide sequences upstream of the ATG are totally divergent.

In the murine Hox 1.1 gene, the discussed upstream reading frame is terminated by a stop codon which overlaps with another ATG initiating a second reading frame, which again terminates with a stop codon overlapping with the ATG initiating the homoeodomain protein frame. This unusual arrangement is particularly suitable for a translational control mechanism, as translation of the first or second frame will inhibit translation of the homoeodomain-containing frame? ${ }^{7}$. Taking into account the described evidence from the Hox 1.1 genes, and considering also the presence of upstream ORFs of different primary structure on vertebrate homoeobox RNAs such as the murine Hox 1.3 (ref 8,9 ), Hox 3.1 (G. Breier, unpublished data) and Hox 1.1, the human C13 and C8 (ref. 6), and the Xenopus X1Hbox2 (ref. 5) and Xhox-36 (ref. 3), a translational control mechanism may well involve upstream ORFs and, at least in Hox 1.1, the encoded peptide may be important enough that it was conserved between frog and mouse.

Michael Kessel Peter Gruss

Department of Molecular Cell Biology,

Max Planck Institute of Biophysical

Chemistry,

Am Fassberg, 3400 Göttingen, FRG

1. Bürglin, T.R., Wright, C.V.E. \& De Robertis, E.M. Nature 330, 701-702 (1987).

2. Kessel, M. et al. Proc. natn. Acad. Sci, U.S.A. 84, 5306 (1987).

3. Condie, B. G. \& Harland, R. M. Development 101, 93-106 (1987).

4. Meijlink, F. et al. Nucleic Acids Res, 15, 6773-6786 (1987)

5. Wright, C. V. E., Cho, K. W. Y., Fritz, A., Bürglin, T. \& De Robertis, E. M. EMBO J. 6, 4083-4094 (1987).

6. Simeone, A. et al. Proc. natn. Acad. Sci. U.S.A. 84, 4914 4918 (1987).

7. Kozak, M. Nucleic Acids Res. 15, 8125-8146 (1987)

8. Odenwald, W. F. et al. Genes Dev, 1, 482-496 (1987)

9. Fibi, M. et al. Development 102. (1988)

\section{Where does Africa meet Europe?}

SIR-The Straits of Gibraltar have served mankind many millenia as a morphological milestone separating different continents. To most earth scientists the Seismic Azores Transform Fault, which offsets the spreading pattern in the Atlantic Ocean by about $300 \mathrm{~km}$ (ref.1), extends through the Straits of Gibraltar and separates the African and Eurasian plates in the western Mediterranean. But it is time to reappraise this view, not least because of the consequences for earthquake prediction in Spain and North Africa.
The assumption that the two plates impinge in the Straits is based on a preliminary interpretation of the plate boundary using a scattered distribution of earthquake foci². A recent higher resolution study of earthquake foci $^{3}$ suggests that the Azores Fault does not continue into the Straits of Gibraltar and that no neat linear plate boundary can be identified there ${ }^{3}$. This conclusion confirms previous allegations made

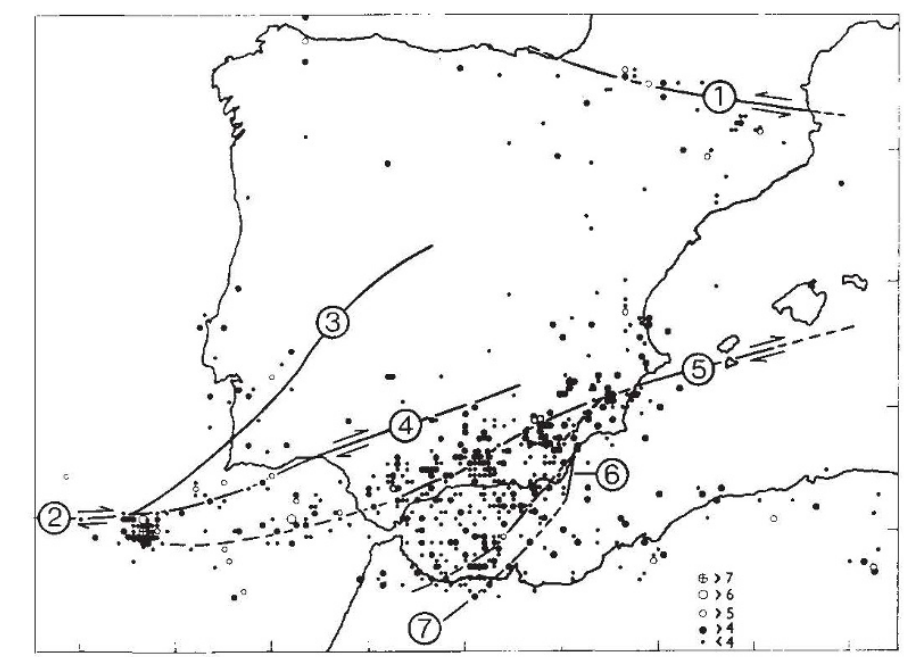

Distribution and magnitude of earthquakes recorded by the Spanish Seismological Survey (Madrid) ${ }^{4}$ during the period 1961-72. Major lineaments mapped ${ }^{5}$ so far are: 1, North Pyrenean Fault; 2, Azores Transform Fault; 3, Plasencia lineament; 4, Guadalquivir lineament; 5, Crevillente Fault; 6, Palomares Fault; and 7, Nekor Fault.

on the basis of the diffuse nature of seismic activity in the Straits and the adjoining Alboran Sea ${ }^{4}$.

Although high-resolution plots of earthquake epicentres can sometimes limit the location of major active strike-slip faults, the current deformation in the western Mediterranean is apparently distributed over so many faults that detailed field mapping provides a better means to achieve this. I have recently attempted to correlate the detailed maps and field observations made by several generations of geologists of a variety of nationalities ${ }^{5}$. As shown in the figure, compilation of the traces of major lineaments $\mathbf{i}$ have so far mapped in the western Mediterranean ${ }^{5}$ together with the seismic data ${ }^{4}$ suggests that the Azores fault passes east into a diffuse zone of splay faults in southern Spain and the Alboran Basin. The creation of the Straits of Gibraltar themselves has now been explained simply by local subsidence and erosion of the Betic-Rif Orogen or Arc of Gibraltar during the late Messinian only five million years $a^{6} o^{6}$. This subsidence also terminated the so-called Messinian salinity crisis, which involved the deposition of up to one kilometre of salt onto the floor of the Mediterranean Sea between five and seven million years ago ${ }^{6}$.

A previous alternative explanation of the tectonic boundary between Europe and Africa also appears to be untenable. High-pressure, low-temperature metamorphism in the deeper nappes of the Betic Cordilleras had been used to argue that the suture between the African and Eurasian plates may be a subduction zone hidden within southern Spain? ${ }^{7}$ But recent investigations suggest that the peak of this metamorphism in the Betic Cordillera occurred 80-85 million years ago ${ }^{8}$, some 60 million years before the formation of the Betic-Rif Mountains ${ }^{5}$. This implies that the ancient subduction zone suggested by the exposed high-premure low-temperature rocks relates to a former plate boundary but not to the present-day suture.

I have recently suggested that the North Pyrenean Fault forms the modern southern boundary of the stable foreland of western Europe, and that the HayesSouth Atlas Fault is the northern boundary of the stable part of the African plates. The area between these faults can be interpreted as the Iberian microplate which indents Italy in a fashion similar to the impingement of the Indian plate with Tibet before continental collision. This proposition would reduce the size of the African plate by 2 million $\mathrm{km}^{2}$, but needs careful testing in the future.

Unfortunately the only research group studying active faults in the western Mediterranean does not include the South Atlas Fault in its programme'. Details of the geology, seismic data and aeromagnetic anomalies are still unclear. Such studies are important not only for solving the complex nature of the plate boundary but also to increase the accuracy of predicting earthquakes that might put Mediterranean people, particularly in Spain, Morocco, Algeria and Tunisia, at risk.

Ruud WeIJERMARS

The Hans Ramberg Tectonic Laboratory, Institute of Geology, Uppsala University, Box 555, S-751 22 Uppsala, Sweden

1. Rona, P.A. NOAA Atlas 3 (US Dept. of Commerce, National Oceanic and Atmospheric Administration, Miami, 1980).

2. McKenzie, D.P. Nature 226, 239-243 (1970)

3. Grimison, N.L. \& Chen, W.P. J. geophys. Res. 91, 20292047 (1986).

4. Udías, A., Arroyo, A.L. \& Mezcua, J. Tectonophysics 31, 259-289 (1976).

5. Weijermars, R. Geol. Rundschau 76, 667-676 (1987).

6. Weijermars, R. Tectonophysics (in the press).

7. Platt, J.P. \& Behrmann, J.H. J. struct. Geol. 8, 15-33 (1986).

8. De Jong, K. Conf. Geol. kinernat. dynamics (Abstr.) Uppsala, 22-24 April 1987.

9. Hancock, P., Boccaletti, M. \& Moratti, G. J. struct. Geol. 9 , $255-257$ (1987). 